\title{
Understanding the Coordination Mechanisms in a Fair Trade Fruit Supply Chain
}

\author{
Luciana Marques Vieira, PhD \\ Postgraduate Progam in Management, UNISINOS. \\ lmvieira@unisinos.br \\ Luís Kluwe Aguiar, Msc \\ Royal Agricultural College (RAC), \\ School of Business \\ luis.aguiar@rac.ac.uk \\ Marcia Dutra de Barcellos, $\mathrm{PhD}$ \\ Master School in Business Administration (MAN) \\ Pontifical Catholic University of Rio Grande do Sul (PUCRS) \\ marcia.barcellos@pucrs.br
}

\begin{abstract}
Globalization of food supply chains requires from companies located in developing countries to comply with strict production standards. Hence, there is an increasing need for socio-economic environmental certification worldwide. A way to meet food standards is to create a supply chain management that deals with sequential processes coordinated by the chain leader. In the particular case of agri-food markets, it is common for food retailers to perform the role of chain leaders. This paper describes the configuration and coordination of a certified fair trade fruit supply chain in Brazil servicing the United Kingdom (UK) market. The methods used are interviews with key informants working at different stages of the supply chain in both countries and secondary data analysis. Our findings suggest that retailers in the UK transfer the responsibility of supply chains coordination to their partnering traders in Brazil, who, in turn, are responsible for monitoring information flow and tracking processes. Theoretical contributions are related to the understanding of a complex supply chain because it involves members that have different technologies, skills, language and knowledge about the market. This heterogeneity makes the co-coordinating role even more important.
\end{abstract}

Keywords: fair trade, export, international supply chain, fruit supply chain management, coordination

\section{INTRODUCTION}

Recent decades have witnessed a surge in the globalization of food chains. Such a phenomenon has affected food supply chains, with increasing level of homogenization of consumption preferences. In developing countries, this convergence of demand has led companies to adopt standards of production for their trading partners. As a result of such adoption, these standards, when compared to those required by emerging countries' markets, have shaped rules and regulations which ultimately have also benefited domestic consumers (Vogel, 1995).
Food production and processing standards are fundamental to market access. Particularly in developing countries, producers must raise their standards to maintain their export markets or to gain access to high value ones. The world-wide proliferation of food standards has stimulated an increasing need for certification to assure not only food safety, but also social, economic and environmental improvements. Nevertheless, some of these food standards may be incompatible with prevailing systems of both production and marketing in developing countries, due to imposing good agricultural and manufacturing practices which are expected by international buy- 
ers, but that, in reality, impose challenges and higher costs of production (Jaffe \& Henson, 2004).

The globalization of food chain is characterized by a division of stages of production which are located at different sites. Diverse countries provide resources such as labor and raw materials that end up contributing to a final product. This network of commodity exchange binds producers and consumers across the world under the dominance of large agro-food transnationals (Dolan \& Humphrey, 2000; Farina, 2002; Reardon et al., 2001).

The World Fair Trade Organization (WFTO) defines their network as a trading partnership, which is based on dialogue, transparency and respect, and that seeks greater equity in international trade. It contributes to sustainable development by offering better trading conditions to, and securing the rights of, marginalized producers and workers - especially in the South (WFTO, 2009). Low and Davenport (2006) tell that Fair Trade (FT) started as an alternative way of commercialization but nowadays FT uses conventional marketing channels such as large retail chains. While fair trade channels can provide opportunities to small farmers, the initial certification costs can be high and limit the potential outreach of the fair trade alternative (Vieira \& Aguiar, 2009). The fair trade label is essentially a private one and operates in parallel to conventional trading mechanisms.

For the purpose of this study, to ensure that Brazilian food smallholders could benefit from the FT system, there is a need for a greater understanding of the configuration and coordination of this supply chain. Therefore, the aim of this study is to identify both the configuration and the co-ordination of the fair trade supply chain.

In the next section, the paper presents the literature background of the study focusing on supply chain management and fair trade market. Then, it follows presenting the study methodology. The study combines different methods of gathering information such as the use of publicly available data (sites, retail folders, British newspapers and magazines, among others) and a chain of interviews (with key informants, each one being an expert in a different stage of the process). Key informants encompass fruit producers in Brazil, UK importers, certifying bodies and a grocery manager of a British supermarket chain. Finally, the study triangulates data from different sources to draw the main findings and implications.

\section{LITERATURE BACKGROUND}

\subsection{Supply Chain Management}

Mentzer et al. (2001) define supply chain as a set of three or more agents directly involved in input and outputs flows of products, services, financial resources and information from the origin to the end consumer. Still, according to these authors, supply chain is a phenomenon which always occurs when companies establish relationships, independently of the level of management. This statement distinguishes the supply chain from supply chain management, meaning that the latter is the systemic and strategic coordination of tasks among different companies that are part of a supply chain, aiming to improve each company's performance as well as the overall supply chain.

The concept of supply chain management (SCM) has changed the competitive paradigm, when scholars consider that competition happens amongst supply chains, thus providing flexibility. Flexibility and chain competition are key concepts on agrofood systems, which have been recently becoming more concentrated and responding to changing demand. Nevertheless, the applicability of SCM is difficult in some sectors due to opportunistic relationships present amongst agents. A key issue in supply chain management is coordination. In the literature, terms such as integration (combining to an integral whole), collaboration (working jointly) and cooperation (joint operations) are elements that support coordination (Arshinder et al, 2008). Yet, when coordination problems rise, these relate to difficulties in the ability to coordinate different processes and to collectively consider the costs of different processes that would minimize overall costs of the SC. These problems have been usually resolved through the use of contracts, information technology, information sharing and joint decision making (Arshinder et al, 2008). The study of relationships among firms makes possible the identification of the driving forces that motivate them to chain co-ordination (Boehlje et al., 1998; Dyer \& Singh,1998).

SCM as a strategy assumes that there is usually a leadership role or function responsible for the co-ordination of the actions of each agent involved in the supply chain. The interdependence of agents is described as sequential i.e. where the final product of an agent is the primary product of the next agent. In this case, the mechanism of co-ordination results in the planning formulated by the leader of the chain. 
This leader is, therefore, responsible for the production planning, information monitoring, promotion, and changes to the competitive environment, amongst others. It is usually the powerful agent that manages the relationships throughout the supply chain (Chen \& Paulraj, 2004).

In agro-food markets, it is also important to analyze the value perceived on products by customers. This is especially true to those still considered as commodities. The strategy of differentiation and branding helps to add value to commodities, consequently increasing profits. The main motivation for companies to line up with the SCM concept is to strategically achieve product differentiation or to control product quality (Boehlje et al., 1998; Vinholis, 2000, Vorst et al., 2000).

Chain orientation towards end-consumer is also fundamental for the organization of all agents. A supply chain will only be competitive if it is connected with the demand and consumers' needs. The progressive reversal of food supply chains from being supply to demand driven has made an enormous difference to their structure and modus operandi (Bose lie, Henson \& Weatherspoon, 2003). Although recent literature points out for a trend for a supplier base reduction (Chen \& Paulraj, 2004), UK retailers have been including small producers from developing countries through the FT label. However, SCM does not come without its difficulties. The clear identification of demand and its trends and the ability to communicate this (information transfer) backwards through the chain, which would result in determining both product and processes standards, still encounter important constraints.

Increasingly, food retailers have become chain cocoordinators due to their access to market information (Vesser et al., 2000). Supply chains coordinated by supermarkets are essentially different from other marketing channels. While the latter can be fragmented and multilevel, supermarkets' chains are shorter and involve direct delivery to distribution centers (Boselie, Henson \& Weatherspoon, 2003). Supermarkets act as chain leaders by enforcing and communicating technical information about quality grades and standards which suppliers must comply with. As a consequence, this improved and more direct communication reduces information costs and risks. Nonetheless, in some cases, suppliers of supermarkets have less access to consumer information in comparison with, for example, local markets, that brings implications for their bargaining position.
In this study, it has also been depicted power and information asymmetry between large retail chains and fair trade smallholders from developing countries. Those retailers interested in commercializing FT products ought to pay more attention to asymmetric imbalances should they wish to develop suppliers. These differences between the supermarkets and small producers create interesting insights for the SCM studies.

\subsection{Fair Trade Market}

FT originated in the 1960s, when Non-Governmental Organizations (NGOs), European and American consumers groups started selling products made by small producers victimized by poverty or by commercial isolation (WFTO, 2009).

On the second half of the 1980s the first formal initiatives of collaboration amongst a FT chain appeared. Today, the FT counts on a large number of organizations spread all over the world. The most widespread FT concept was adopted in the annual International Federation Alternative Trade (IFAT) Conference which occured in Arusha, Tanzania, in 2001. In that conference a definition of Fair Trade emerged which could be better described as a commercial partnership based on dialogue, transparency and respect, aiming at equality amongst stakeholders of the shared supply chain. FT products were initially sold in churches and small charity shops, where the consumers and sellers had a trustworthy relationship. In a second stage of the FT evolution, the FT products reached the market through the Alternative Trade Organizations (ATO`s), that identified market opportunities for key products, imported and commercialized them through a variety of channels as church fairs, internet and own shops, among others (Jones et al., 2004).

In the UK, fair-trade products can be purchased from specialist retailers trading in alternative products. In the 2000s, FT initiatives promoted the idea that changes in the retailing structure should be made, benefiting the society in general. Basically, traditional retail outlets such as major supermarket chains and other large specialist food retailers in the UK should also sell fair-trading products as part of their food assortment. Subsequently, the conventional food-retailing sector rapidly reacted. In the pursuit to follow a growing trend, large food retailers made it possible for FT to become mainstreaming. It is also true that this has helped many food companies to 'clean their act', that is, many corporate social re- 
sponsibility statements presently include reference to some form of fair-trading (Jones et al., 2007).

The early 2000s also saw another phenomenon arising. FT goods were no longer a typical and exclusive product controlled and moved by the many fair-trading certification bodies. In the UK, specialist food retailers such as Marks\&Spencer (1994) and Waitrose (2007) not only carried an increasing range of fair-trading goods but also embarked on their own fair-trade initiatives.

Other larger food retailers followed these trends in close pursuit under the Ethical Trading Initiative ETI, which had initiated in the late 1990s (ETI, 2007). The ETI works under an alliance of companies, nongovernmental organizations (NGOs) and Trade Unions aiming at improving the corporate code of practice of its members, which covers working conditions in the supply chains. Such an initiative quickly attracted large food retailers in the UK as it attempts to regulate and improve labor conditions in sites of production so that international standards are met, hence, fulfilling some of the fair-trade criteria with regard to the human dimension.

Presently, the UK is the third largest market for fairtrade products in Europe, after Germany and Holland, which provides opportunities for fair trade products to be consumed in ever differentiating formats. Fair trade products can be found in universities, both governmental and private offices, schools, coffee shops, vending machines, service stations and fast food chains, to name some outlets. The distribution of fair-traded products entering the four largest food retailers in the UK is a testimony of the popularization of fair-trading.

However, it also means that such an initial typical niche market has indeed finally broken into mainstream. The figures of growth and performance indicate that, whilst in 2005 some $£ 200$ million fair trade worth of goods was sold in the UK, by 2009 it had reached $£ 800$ million (Fair Trade Foundation, 2010). This growth supports the direction that many corporations have taken in respect of their corporate and social responsibility strategies, as mentioned before. Angela Webb, a BBC journalist, stated that in 2005 the fair trade market grew by $40 \%$ (BBC, 2006). This data is, for example, supported by Tesco (2007), presently number one food retailer in the UK that claims to have some 130 different fair trade lines in its outlets. ASDA, other important food retailer in UK, has also fair-trading in its corporate responsibility statement and is also a member of the Ethical Trading Initiative. J Sainsbury's (2007) is on its turn proud to be the leader in the sales of fair-trade bananas and has recently created a Fair Trade Development Fund. Such a fund is responsible for supporting many initiatives in fair-trade producing countries. The John Lewis Partnership, through its food retail arm, Waitrose, has created the Waitrose Foundation whose mission is to foster many projects in South Africa, especially in citrus groves. Marks\&Spencer has launched "Plan A". This is a five-year plan aimed at addressing challenges around the world which include the safeguard of natural resources and ethical trading. Marks\&Spencer carrying 100\% own-brand products makes claims that its fair-trading commitment benefits over one million farmers and workers.

Furthermore, fair trade essentially involves a code of practice to meet consumers' needs. As Ellis and Higgins (2006) point out, it is a 'voluntary' regulation to meet differentiation standards. This notion has been recently captured and is easily enforced by retailers. FT supply chain is even more complex than other SCs because it involves members that have different technologies, skills, languages and knowledge about the market. This heterogeneity of the members of the FT supply chain could act as a barrier to co-operation. As a result the co-coordinating role becomes even more important.

Based on this discussion, some questions arise: (1) Which are the roles of the agents within a fair trade supply chain? and (2) Which roles each agent performs throughout the supply chain in the initiatives led by the UK retail?

\section{METHOD}

This study relies on descriptive and exploratory techniques, aiming at bringing insights to the development on this field of research (Yin, 1994). The experience of the researcher comes into play into assigning priorities to problem areas for further research. In this study, different techniques were used such as: three interviews with key informants selected because they possessed special knowledge or experience in studying this particular topic and four in-depth interviews with agents positioned in different parts of the supply chain (supermarket, importer, and trader, co-operative). These interviews were carried out in the UK and Brazil in the first semester of 2009 and lasted around one hour each one. In-depth interviews discussed issues such as: 
the extension with which fair trade facilitates access to markets, definition of standards and participation in the process and supermarkets strategies to choose fair trade products.

The following table was adapted from Sterns et al. (1998) and Westgren and Zering (1998) from the original developed by Yin (1994). Below, is proposed an application of the table relating it to this research focus.

Table 1: Unit of Analysis

\begin{tabular}{|l|l|l|}
\hline & Single-case design & Multiple-case design \\
\hline Single unit of analysis & Supply chain & Supply chains \\
\hline & Supply chain & Supply chains \\
Multiple units & $\bullet$ Producer & $\begin{array}{l}\bullet \text { Producer } \\
\text { (embedded case) }\end{array}$ \\
& $\bullet$ Processor & $\bullet$ Retailer \\
\hline
\end{tabular}

In this study, the unit of analysis is multiple, which means the different agents existing within a direct supply chain. This brings advantages such as providing an observation of a phenomenon, which is slightly different according to distinct contexts (Miles \& Huberman, 1994). However, while it was not possible to interview the different agents at the same time (as in a focus group), they were analyzed as members of the same supply chain (single case design).

The last step consisted of the transcription of the narratives provided by the interviewees and secondary data analysis. The transcription process tries to abstract and simplify the record of the events (Riessman, 1993). The interviewees consider a narrative from their own vantage point, of view adding to the emergent analysis options and alternatives (Garud et al., 2006). The use of narratives is common on social sciences and organizational studies, and it provides richness for the supply chain studies, where agents are positioned on different part of the chain and therefore perceive it in diverse ways. In order to check its validity, the resulting analysis was disclosed to the key respondents to verify the veracity of the information gathered. Any claim was supported with multiple evidences, whenever possible (Miles \& Huberman, 1994; Yin, 1994).

The supply chain studied is product specific, in this case, a FLO fruit supply chain. Fruits are produced in Brazil by small holders in the Southern region and traded by a local branch of a UK fruit importer. The importer is responsible for supplying the fruit for the major supermarket chains in the UK. The roles of external agents such as ETI and the FLO office in Brazil were also assessed.

The interviews were carried out in the beginning of 2009. In the UK, the interviews were made with a category manager of a British retail chain, a manager of a fruit import company and with a member of the ETI. In Brazil, the respondents were a fruit trader, a fruit co-operative and a member of the FLO in São Paulo. Each interview lasted about one hour and was analyzed according to the literature review and in the light of each member's (internal or external) position in the supply chain. In addition, an analysis of supermarkets websites and folders was also carried out in an attempt to understand how FT is strategic for these retailers.

The interviews with agents involved in the FT supply chain focused on the following issues:

- activities carried out by the company

- motivations for choosing fair trade products

- interactions with other agents (suppliers, customers) and to what degree

- input and output features

- the way information is collected

- the way prices are determined

- problems perceived in the supply chain

- impact of food standards and safety measures

The data gathered from secondary and primary sources was analyzed through explanation building (Yin, 1994). This means to define a set of causal links about the phenomenon under investigation. This 
technique is opened with loose theoretical propositions revised at successive stages. For this qualitative analysis, the software N-VIVO was used, grouping and relating the concepts used and applications of the interviews made. The interviews were conducted with individual firms, but the analysis tried to see them in a chain context. Thus, all the information gathered was analyzed in the wider context, identifying the links and relationships between the agents of the chain (how agents interact) aiming to design the supply chain dynamics.

\section{FINDINGS}

\subsection{British Retailers}

The retail sector is highly concentrated and very competitive in the UK (Hollingsworth, 2004). Their changes in supply chain management practices through the development of tight relationships with food suppliers are present in recent literature (Ellis and Higgins, 2006; Jone et al., 2004, Hornibrook et al., 2005). In the light of increasing environmental awareness among consumers, retailers have been putting considerable effort into portraying a greener and more neighborly image, as they no longer compete just on price, but also on ethical behavior. As such, food labeling has proved to be a further point of differentiation between the big chains (EUROMONITOR, 2007). Jones et al. (2007) identify that the top UK retailers used related Corporate Social Responsibility (CSR) themes within stores to inform customers about specific products, predominantly on organic and FT products, healthy living ranges and local produce. Barrientos and Smith (2007) specifically examine the role of supermarkets to the rapid growth of Fair Trade in the UK. These authors understand that this process is consumer-led.

In this research, firstly, we analyzed three websites of retail chains more involved in FT commercialization to better understand the discourse on FT products as well as producers. This was regarded important because the messages are considered integral part of their commercialization strategies. The three supermarket chains studied were the Co-operative Food, Tesco and Waitrose.

While the Co-op states in its CSR that it aims "to enhance the lives of our people, members, customers, and the communities in which we trade", yet, Waitrose affirms that "Our key policies and positions on CSR issues, goes from fair trade, child labor and climate change to animal welfare, accessibility, and community investment". In a less clear way, Tesco uses the concept of sustainability as it main CSR (social, economic and environmental) message.

Regarding working with suppliers, Tesco makes clear from its website "Ethical trading: sourcing from many different countries around the world - some highly developed and some less developed, with differing standards of regulation and enforcement." The three supermarket chains have large statements regarding fair trade. The Co-op emphasizes that "by working in partnership with co-operatives in the developing world, co-operatives in the UK are demonstrating new shared values with like-minded people across the globe".

These statements reinforce that retailers use FT as part of the CSR discourse to show proximity to small suppliers from developing countries. When regarding the FT discourse, it appears that a tight relationship has developed between retailers and small producers abroad.

After this first step, a semi-structured interview was carried out with a category manager of a large retail chain to describe the purchasing process and the agents involved in this SC.

During the interview with the category manager of one of these retail chains (who asked not to be identified), it was clear that the purchasing process was delegated to a third party. In this case the agent was a British importer with branches in several developing countries. Although the supermarket manager recognized that once or twice per year he travelled to visit the sites of production, the entire process was run by a third party. That manager also stated that no concerns regarding the fruit origin or provenance were ever raised as the fruit arrived at the distribution centre accompanied by the FLO certification within the set specified format and color standards. The category manager was responsible for both certified and conventional fruits and there was no need for segregation on the supply chain, apart from the requirement of FLO label.

\subsection{British Fruit Importer}

The British importer interviewed started to trade FT fruits in the 1990's. At the time of the study, the UK market was worth $40 \%$ of his total business and he dealt with many different products supplied to a range of retailers. Fruits range from pineapples, apples, pears, oranges, limes, lemons, grapefruit, avo- 
cados, mangoes, prunes, among others. These fruits are all FT-certified by organisms such as FLO, BSC and Global gap. The company's turnover is about $£ 12$ million annually. It sources fruit from countries such as South Africa, Mozambique, the Ivory Coast, Peru, Ecuador, Burkina Faso, Ghana and Brazil. In Brazil, for example, the company has a subsidiary which is responsible for the social development and production of some 104 farmers. As an importer, the company has to bear the cost and support the FT initiative for at least two years until it becomes sustainable. At the Brazilian branch, an employee is responsible for the inspection and monitoring of the orchards and someone from head office will make an annual visit to the Brazilian fruit producers. The importer absorbs the costs of those visits (around $£ 6,000$ each) while the FLO certification costs are covered by the small producers. The British importer collaborates with the FLO certification body while establishing standards and prices for fruits. In his opinion, since third world countries are often located in the tropics, the production of FT tropical fruit was seen to have great potential in the Fair Trade market segment.

In this trader's case, he initially approached different supermarkets to check whether there was a market for the Fair Trade products. Around 2004, supermarkets buyers were skeptical when there was only $37 \%$ customer recognition of Fair Trade products. The likes of Marks \& Spencer (M\&S) that only carried their own range products which already helped third world countries were not thrilled to join Fair Trade idea. At the onset of the Fair Trade concept in the UK, each grower's association would approach each supermarket individually. At that time there was no co-operation amongst growers and acting individually growers could not sustain constant throughout over an extended period of months. This meant, for example, that Sainsbury's, who have around 450 stores in the UK, would only have enough to attend the demand to cover 100 stores. Facing issues such as Effective Ordering Quantity Sainsbury's could not stock Fair Trade products and would only offer products such as avocados when they were available. The fruit importer interviews came up with a unique solution that would enable to source and supply Fair Trade products from around the world in order to supply supermarkets with a 52 week supply every year.

As supplier of fair trade produce, the importer sources produce directly from growers' supply who takes over the responsibility to grade, package and ship the fruit which are delivered to the retailers' distribution centers. Providing such a linkage was beneficial to both the producers and the retailers. Whilst the producers are constrained by about a six-week supply of produce window and the supermarkets were looking for a year-round supply for their customers, the trade company now offers 14 different lines of product in the UK market, most with enough supply to attend the supermarkets for uninterrupted 52 weeks of the year.

\subsection{Ethical Trade Initiative}

ETI is an important stakeholder in the FT supply chain. It is an alliance of companies, trade unions and voluntary organizations based in London. This partnership produces guidelines to improve the lives of workers who make or grow consumer goods worldwide. The origins of the initiative goes back to 1998, where a group of UK companies, NGOs and trade union organizations, with the backing of the then Secretary of State for International Development Clare Short, launched a radical approach to protecting workers' rights in global supply chains. Their aim was to build an alliance of organizations that would work together to define how major companies should implement their codes of labor practice in a credible way - and most importantly, in a way that has maximum impact on workers.

The companies that joined ETI in 1998 were ASDA, Premier Brands, The Body Shop, Littlewoods and Sainsbury's. From that handful of pioneers, membership now comprises over 50 companies with leverage over more than 38,000 suppliers, collectively covering in excess of eight million workers across the globe (ETI, 2007). An interview with a senior member representing this organization was held to better understand the role of the different agents on the configuration of ethical supply chains.

According to the respondent, fair trade relates more to sustainability and, as such covers a small part of the bigger picture. On ethical trading FT is judged to be ignoring the bigger dimension that could be more important for the livelihoods of small farmers. In this sense ETI is more marketable as it gives the edge in the consumer's mind. A small producer adhering to FT would have his costs raised due to annual certification payments.

There are a number of motivations behind food retailers for choosing fair trade products such as: to get into the market, to provide something extra to 
consumers and to offer something better than the existing proposition, and, most of all, doing good for the environment makes one company less susceptible to criticism - it is a good business strategy for business continuity.

In the UK, different supermarkets have different approaches to ethical trading. For example, Waitrose follows a different set of standards (it considers itself high-end, top ethics) yet others, such as Morrison's, is not at all committed to ETI. Since standards are norms that must be adhered to, those supplying Morrison's need to carry out a different standard audit from the food retailers members of the ETI. It is felt that if each supplier sets up some specific requirements that factories need to adhere to wish different codes of practices it would become impractical. Hence going to the highest standard should suffice.

The ETI senior member also highlighted that every supply chain is in constant danger of disruption and the argument for fairness and trading certainly ends up strengthening the supply chain by treating the workers better. As a result, the intermediates, importers or retailers would end up being better known, and, consequently, the workers would spread the good news that they are being treated fairly.

\subsection{Fair Trade Labeling Organization}

To understand how fair trade works in practice, it is important to describe what the main requirements to receive the certification are. In order to integrate the FT international criterion and to adopt a common system of certification, was founded the Fair Trade Labeling Organizations International - FLO (FLO, 2005) in 1997. The FLO is responsible for certifying the producers and establishing the FT criterion. It follows international practices accepted by external monitoring and certifies products, giving them a guarantee label. It has social rules of technical specification for the products and it also has some environmental rules for each product. It has branches worldwide and, for this study, an interview was carried out in São Paulo office.

These rules aim to facilitate the acceptance of the products at the international market. The certified food products by FLO (2005) are coffee, tea, cocoa, sugar, fruit juices, fresh and dried fruit, bananas, vegetables, spices and herbs, rice, nuts, oils, wine, beer and rum. Non-food products are also commercialized such as cotton, flowers and sports balls.

The standards enforced by FLO are a set of economic, social and environmental directives that follow certain criteria and conventions internationally recognized. In order to get the FLO certification, the producer organizations must comply with general criteria (applicable to any product) and specific criteria (per product). This set of criteria, discussed in this section, gave subsidies to the drawing up the questionnaire applied in the research and also to the subsequent analysis of the obtained outcomes. Each criterion has minimum requirements to obtain the certification.

Table 2: Criterion for FLO Certification

\section{Criterion for FLO Certification}

\begin{tabular}{|l|l|l|}
\hline Directives and criterion & Minimum requirements \\
\hline \multirow{5}{*}{ SOCIAL DIRECTIVES } & $\begin{array}{l}\text { Criteria 1) } \\
\text { Development Potential }\end{array}$ & $\begin{array}{l}\text { The producer organizations must be able to prove that FT } \\
\text { will make the difference on business and that its benefits will } \\
\text { help in the growth of business and will provide better lives to } \\
\text { the producers and their families. }\end{array}$ \\
\cline { 2 - 3 } & $\begin{array}{l}\text { Criteria 2) } \\
\text { Members of the } \\
\text { organization must be Small } \\
\text { Farmers }\end{array}$ & $\begin{array}{l}\text { Most of the members of producer organizations must be } \\
\text { characterized as small farmers. }\end{array}$ \\
\cline { 2 - 2 } & $\begin{array}{l}\text { Criteria 3) } \\
\text { Democracy, participation } \\
\text { and transparency }\end{array}$ & $\begin{array}{l}\text { Member must control the organization structure. One } \\
\text { possibility is the establishment of a general assembly } \\
\text { that gets together at least once a year and be the supreme } \\
\text { organism to take decisions. The report and the annual } \\
\text { accounts must be approved by all members. }\end{array}$ \\
\cline { 2 - 3 } & $\begin{array}{l}\text { Criteria 4) } \\
\text { Non-discrimination }\end{array}$ & No person can have the participation denied. \\
\hline
\end{tabular}




\begin{tabular}{|c|c|c|}
\hline \multirow{3}{*}{$\begin{array}{l}\text { ECONOMICAL } \\
\text { DIRECTIVE }\end{array}$} & \begin{tabular}{|l|} 
Criteria 5) \\
FT Premium Price
\end{tabular} & $\begin{array}{l}\text { The organization should be able to manage the FT premium } \\
\text { to the producers' benefit in a transparent way. }\end{array}$ \\
\hline & $\begin{array}{l}\text { Criteria 6) } \\
\text { Export Capacity }\end{array}$ & $\begin{array}{l}\text { The organization must have physical assets and be qualified } \\
\text { to export (the indicated volume of } 20 \text { tons, equivalent to } \\
1 \text { container).It should include a telephone line, Internet } \\
\text { access, computer systems and good administrative skills. } \\
\text { The product must follow the present patterns of quality to } \\
\text { export and the organization must show it has or it can export } \\
\text { directly with success or, if necessary, indirectly (through a } \\
\text { partner). It must also have a FT demand clearly established } \\
\text { to the product. }\end{array}$ \\
\hline & $\begin{array}{l}\text { Criteria 7) } \\
\text { Economic Growth }\end{array}$ & $\begin{array}{l}\text { One of FT purposes is to increase the capacity of small } \\
\text { farmers to work in groups and export. The producers must } \\
\text { develop their skills and capacities in order not to depend on } \\
\text { other people which can have opportunistic behavior. }\end{array}$ \\
\hline $\begin{array}{l}\text { ENVIRONMENTAL } \\
\text { DIRECTIVE }\end{array}$ & $\begin{array}{l}\text { Criteria 8) } \\
\text { Environment }\end{array}$ & $\begin{array}{l}\text { Water areas, natural forests and other areas around where the } \\
\text { work is done, must be protected, including erosion problems } \\
\text { and waste management. The environmental monitoring must } \\
\text { be applied. }\end{array}$ \\
\hline
\end{tabular}

Source: the authors based on FLO guidelines

At least, this set of certification criteria gives the guarantee to the consumer that, by buying a FT certificated product, he/she will benefit the whole supply chain. FLO receives payment from every agent part of the supply chain. For example, in this case study, the fruit producers pay an annual fee for the certification. FLO gives a purchasing license to the importer who pays a fixed fee for that. In addition, the retailer pays to FLO a share of the total FT products sales.

\subsection{Brazilian Fruit Co-operative}

The cooperative studied is located in Southern Brazil and it produces 5,000 tonnes of fruits per year. The cooperative has 45 partners and approximately 150 families benefit from it. The organization possesses both organic and FT certification. Exporting activities started in 2005 when FLO certified the producers for citric and tropical fruits such as orange, lime, pineapples, among others.

As such this cooperative has not yet engaged in direct exporting activities. The fruit is commercialized via a local branch of an UK importer who takes over the responsibility of the negotiations. The cooperative's CEO stated that the certification provided a better price from the external market. Apart from exporting to the EU, the cooperative also sells to large retail chains in Brazil. However, domestic food retailers do not pay a premium price for their product. On the other hand, the cooperative's decision has considered strategic not to become dependent on the export market. It sells the fruit under its branded name to the domestic market.

The decision to become organic and FT certified has enabled the cooperative members to improve their livelihoods as they add more value to the end product. Nevertheless, the CEO considered it to be a niche market where the whole negotiation still depends on a third party (trader). The CEO also emphasized that he is aware that the retail chains can source anywhere and all these certification investments can get lost easily. Additionally, he said that the main barriers to direct sales were cultural, regarding language, context, way of being, ways of doing business and relationships.

\subsection{The configuration of the FT supply chain}

The narratives from these different agents help to understand the configuration of this supply

chain. It is represented graphically in Figure 1, where every agent has a relationship with the FLO CERT, which can be characterized as the chain leader or governor and decides who is included or excluded of the FT supply chain. However, the role of the supermarket is also important, because it is a large distribution channel who gives market access to small producers' products in the UK. The supermarket uses FT as part of its CSR but the management of the supply chain is transferred to a third party, in this case, an importer. 
Figure 1. Configuration of the studied FT Supply Chain

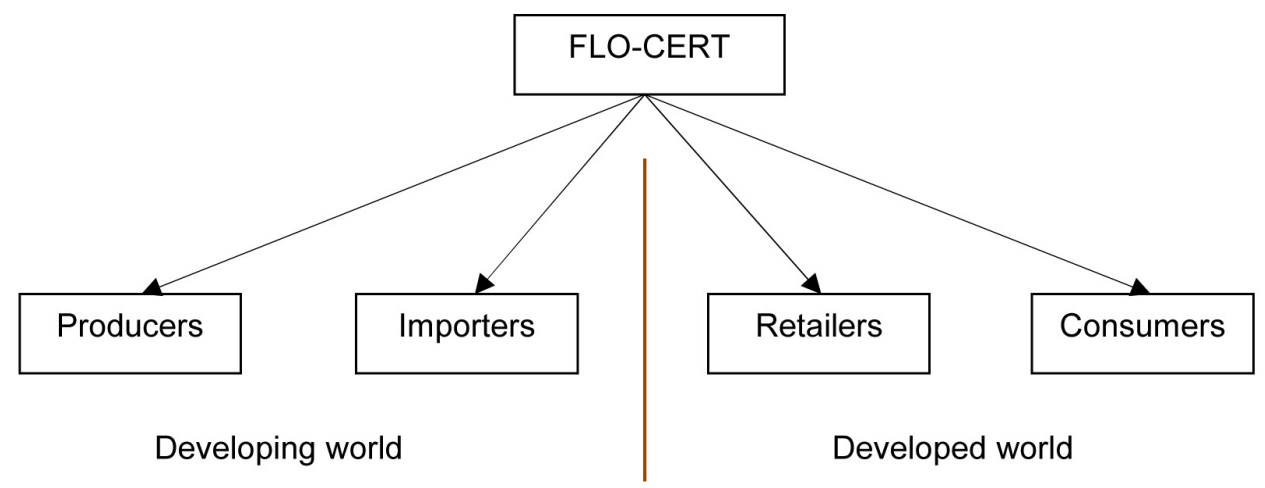

Table 3 helps to synthesize the main findings from each of the agents in terms of configuration and co-

operation in the FT supply chain, from a comparative perspective.

Table 3. FT agents and their role in the Brazilian FT fruit supply chain

\begin{tabular}{|c|c|}
\hline & Role in the Brazilian FT fruit supply chain \\
\hline British retailers & $\begin{array}{l}\text { Retailers are close to the market and have a steady demand for FT products. } \\
\text { They are responsible for the establishment of relationships with suppliers from } \\
\text { developing world and set the main standards. Retailers use third party companies } \\
\text { to proceed with the FT purchasing process. }\end{array}$ \\
\hline British food importer & $\begin{array}{l}\text { Responsible for the purchase of FT certified fruits (FLO, BSC, Globalgap) from } \\
\text { developing countries. Provide a full range of certified fruits from global sources, } \\
\text { allowing the } 52 \text {-weeks per year supply. Inspect and monitor the orchards worldwide } \\
\text { from local branches, absorbing the costs. Work closely with FLO assuring the } \\
\text { standards and prices. }\end{array}$ \\
\hline Ethical Trade Initiative (ETI) & $\begin{array}{l}\text { The Ethical Trading Initiative (ETI) is a ground-breaking alliance of companies, } \\
\text { trade unions and voluntary organizations. The partnership produces guidelines to } \\
\text { improve the lives of workers who make or grow consumer goods worldwide. All } \\
\text { corporate members agree to adopt the ETI Base Code of labor practice, which is } \\
\text { based on the standards of the International Labor Organization (ILO).. }\end{array}$ \\
\hline $\begin{array}{l}\text { Fair Trade Labeling } \\
\text { Organizations International } \\
\text { (FLO) }\end{array}$ & $\begin{array}{l}\text { Founded in 1997, FLO is responsible for certifying the producers and establishing } \\
\text { the FT criterion. It follows international practices accepted by external monitoring } \\
\text { and certifies products, giving them a guarantee label. It has social rules of } \\
\text { technical specification of the products and it also has some environmental rules } \\
\text { for each product. }\end{array}$ \\
\hline Brazilian fruit co-operative & $\begin{array}{l}\text { Located in south Brazil, gathers fruit producers that are FT certified by FLO. The } \\
\text { costs of certification are high, but compensate the exports. The internal market } \\
\text { does not pay a premium price. They supply foreign retailers throughout third } \\
\text { party traders (in this case the British food importer) and comply with the set } \\
\text { standards. They have no guarantees of long term relationship/contract with UK } \\
\text { retailers and the return over the certification investments is therefore uncertain. }\end{array}$ \\
\hline
\end{tabular}




\subsection{The distribution of the economic value in FT: an illustration in the pineapple case}

As the investigation proceeded, it was also possible to estimate a FT pineapple price throughout the sup- ply chain (in British pound sterling). This was not the main aim of the paper, but it helped to illustrate the distribution of the economic value across agents, as seen next:

Table 3 - Estimated FT pineapple price throughout its supply chain (per unit)

\begin{tabular}{|l|c|}
\hline \multicolumn{1}{|c|}{ Stages } & Price (f) \\
\hline Fruit producer & $\begin{array}{c}0.16+0.04 \text { FT premium } \\
\text { (around 8\% end consumer price) }\end{array}$ \\
\hline Packing, local freight & 0.67 \\
\hline International transport & 0.26 \\
\hline Import, certification and distribution & 0.46 \\
\hline Commercialization margin & 0.95 \\
\hline End consumer price on the shelf & $£ \mathbf{2 . 5 4}$ \\
\hline
\end{tabular}

As it can be seen from Table 3, FT pineapple producers are able to obtain around $8 \%$ of consumer end price, a $1.6 \%$ premium if compared to non-FT producers. Nevertheless, supply chain agents responsible for packing (local distributor) and commercialization (mainly retailers) are the ones contributing more intensely to increase in prices to the end consumer (by $26.37 \%$ and $37.40 \%$ ), respectively. Besides, although the certification costs are high, it provides a niche market access and better commercialization margin than conventional production.

\section{FINAL CONSIDERATIONS}

In this paper, we describe how FT movement developed specially as British supermarkets have increasingly sourced products from smallholders and have made them available to consumers on their shelves. This has been considered important not only regarding market access but also in respect of benchmarking of Corporate Social Responsibility (CSR). Smallholder Brazilian farmers find it difficult to access export markets and, hence, good CSR practice could constitute an opportunity for products from Brazil. A combination of factors influence the market, involving government initiatives, private organizations interests, NGOs and the third sector growing influence in trade matters as well as greater consumers' awareness of all these issues, in order to promote the empowerment of small producers. One important factor in the UK, around
2007, was the shift in Fair Trade products' perception. They started being perceived as 'premium' products and sold at 'premium prices'. Apparently, mainly due to shortages of supplies, prices started going up. Fairtrade businesses benefited immensely from an increase in brand awareness and from the possibility of going mainstream, using the existing much wider distribution channels of large retailers.

In this exploratory case study, we described the configuration of a FT supply chain, especially the role of retailers. Then, it is possible to say that retailers are wide spreading the FT concept, but also that the FLO-CERT is the chain leader and manages its name as a brand. Different agents pay to get access to this premium market and have relationship with the FLO-CERT. Secondary evidence shows that there is a trend of retailers to develop their own standards and not using a third certification body (such as Morrison's in the UK and Wholefoods in the US). These standards can be related to risk management or differentiation strategies (Humphrey \& Henson, 2008) and we suggest this topic for further investigation.

Regarding the small producers, they access external market but this relationship is not as tight as promoted by FT discourse. Supermarkets are including FT products but the SCM is transferred to an intermediary (in this case, an importer with branches abroad). This creates a concern on how easily replaced these producers can be and there is an awareness of get- 
ting overspecialized. In this research, some new trends such as the preference for local food due to environmental concerns (bad reputation, deforestation, among others) also were mentioned.

The configuration of the FT supply chain is different from other food supply chains previously studied in the UK (Dolan \& Humphrey, 2000; Hingley et al., 2005; Hornibrook et al., 2005). The difference found is that the relationship between buyer and supplier is not direct as well as the presence of an external agent (FLO certifier) which exercises an important role as chain coordinator (Arshinder et al.,2008). As a result, the costs and gains are distributed amongst the agents, with the fruit producer receiving around $8 \%$ of the end consumer price. It can be concluded that whilst the British retailer provides a market for ethically produced fruit, it delegates the compliance with a system to an agent in the country of production. The FLO certifier guarantees the distribution of value through inspections and the collection of a rent-type fee. We found that this configuration is unique and should be better understood in further studies in other products chains.

The literature proposes that FT is an alternative route to market, but in fact what it seems to show is that FT is simply another entry door into established distribution systems. This point is actually made by the data showing that Fair-trading marketing is moving towards becoming dominated by large food retail formats carrying branded fair-trade merchandises in the UK. The exploratory research identified a FT configuration where there are a number of intermediaries involved in between the transaction of fruit export to the British supermarkets. Opposite to other case studies regarding African producers (Barrientos \& Smith, 2007) there are some difficulties in this supply chain since cultural barriers, such as use of language, negotiation, full understanding and compliance with FT standards, needed a closeness that operations in Brazil could provide.

The study findings suggest that FT is a branding which competes against other leading brands. Although this study is an exploratory case study and cannot be generalized, we suggest further research on other chains and other developing countries to further understand the evolution of FT worldwide through a supply chain perspective. The use of narratives, which is not common in operations management, is also useful to understand the configuration and coordination of supply chain.

\section{REFERENCES}

Arshinder, Kanda,A. \& Deshmukh, S.G, (2008) Supply Chain Coordination: Perspectives, empirical studies and research directions. International Journal of Production Economics, 115, 316-335.

Barrientos, S. \& Smith, S. (2007) Mainstreaming Fair Trade in Global Production Networks: Own Brand Fruit and Chocolate in UK Supermarkets in Raynolds, L., Murray, D., \& Wilkinson, J. (eds). Fair trade in the agriculture and food sector: analytical dimensions. London: Routledge.

BBC. (2006). Is fair-trade fair? Retrieved May, 12, 2006, from http://www.news.bbc.co.uk/1/business/4788662

Boehlje, M., L. Schrader \& J. Akridgel (1998) Observations on formation of food supply chains. In: Ziggers, G. W; Trienekens, J. H. and Zuurbier, P. J. P. (eds) Proceedings of the third international conference on chain management in the agribusiness and the food industry. Wageningen: Wageningen Pers.

Boselie, D., Henson, S. \& Weatherspoon, D. (2003) Supermarket Procurement Practices in Developing Countries: redefining the roles of the public and private sectors. American Journal of Agricultural Economic, 85, 1155-1161.

Dolan, C. S. \& Humphrey, J. (2000) Governance and trade in fresh vegetables: the impact of UK supermarkets on the African horticulture industry. Journal of Development Studies, 37, 147-176.

Dyer, J. H. \& Singh, H. (1998) The relational view: cooperative strategy and sources of interorganizational competitive advantage. Academy of. Management Review, 23, 660-679.

Ellis, N \& Higgins, M.(2006) Recatechizing Codes of Practice in Supply Chain Relationships: Discourse, Identity and Otherness, Journal of Strategic Marketing, 14, 327-350.

ETI (2007). Ethical Trading Initiative. Retrieved June 12, 2007, from http://www.ethicaltrade.org

Fair Trade Foundation (2010), Retrieved 23 June, 2010, from http://www.fairtrade.org.uk/press_office/press_releases_ and_statements/february_2010/public_loyalty_to_fairtrade_ in_2009s_tough_economic_climate_leads_to_double_digit_ growth_as_fairtrade_sales_reach_800m.aspx

Farina, E. M. M. Q (2002) Consolidation, Multinationalisation and Competition in Brazil: Impacts on Horticulture and Dairy Product Systems. Development Policy Review, 20/4, 441-457.

FLO Fair Trade Foundation (2008) Fair trade sales reach half billion pounds. Retrieved 7 March 2010. Retrieved 7 March 2010 from http://www.fairtrade.org.uk/press_office/press_ releases_and_statements/feb_2008/fairtrade_fortnight_ launch.aspx.

Garud, R., Kumaraswamy, A.. \& Sambamurthy, V. (2006) Emergent by design: performance and transformation at Infosys Technologies, Organization Science, 17, 277-286.

Henson, S.\& Humphrey, J. (2008) Understanding the Complexities of Private Standards in Global Agri-Food Chains. Proceedings of the International Workshop on Globalization, Global Governance and Private Standards, Leuven, Belgium. 
Hornibrook, S and Duffy, R and Fearne, A (2005) Justice in UK Supermarket Buyer-Supplier Relationships. International Journal of Retail and Distribution Management, 33 (8). pp. 570-582. ISSN 0959-0552.

Jaffee, S \& Henson, S. (2004) Standards and agro-food exports from developing countries: rebalancing the debate. World Bank Policy Research Paper. Washington:. World Bank Press.

Jones, P. Comfort, D.\& Hillier, D. (2007) Marketing and Corporate Social Responsibility within food stores. British Food Journal,109, 582-593.

Hingley, M, Lindgreen, A., and Casswell, B. (2006) Supplier-Retailer Relationships in the UK Fresh Produce Supply Chain. Journal of International Food Products and Agribusiness Marketing. Vol. 18, Issue 1/ 2, pp.49-86.

Hingley, M. (2005) Power imbalanced relationships: Cases from UK fresh food supply. International Journal of Retail and Distribution Management, Special Issue. vol. 33, issue 8, pp. 551-569.

Low, W., \& Davenport, E. (2006) Mainstreaming fair trade: adoption, assimilation, appropriation. Journal of Strategic. Marketing, 14 (4), 315-327.

Mentzer, J. T. et al. (2001) Defining supply chain management. Journal of Business Logistics, 22, 1-25.

Miles, M.B. \& Huberman, A.M (1994).Qualitative Data Analysis,
Newbury, CA: Sage publications.

Jones, P., Comfort, D., \& Hillier, D. (2004). Developing customer relationships through fair trade: a case study from the Retail Market in the UK. Management Research News, 27(3), 77-87.

Reardon, T. \& Farina, E., (2001) The Rise of Private Food Quality and Safety Standards: Illustrations From Brazil, International Food and Agribusiness Management Review, 4(4), 413-421.

Riessman, C.K.(1993). Narrative Analysis, Sage, Newbury Park, CA.

Sterns, J.A., Schweikhardt, D.B. \& Peterson, C.H. (1998) Using Case Studies as an Approach for Conducting Agribusiness Research, International Food and Agribusiness Management Review, 1, 311-327.

Vieira, L.M. \& Aguiar, L.K.(2009)An appraisal of the Fairtrade system: evidence from small producers in emerging countries. In: Lindgreen, Hingley and Vanhamme. (eds). The Crisis of Food Brands: sustaining safe, innovative and competitive food supply.(pp.327-346) Aldgate: Gower Publishers.

Vogel, D. (1995) Trade Up: Consumer and Environmental Regulation in a Global Economy, Harvard University Press.

Westgren, R. \& Zering, K. (1998) Case Study Research for Firm and Market Research, Agribusiness, 14(5), 415-423.

Yin, R.K. (1994) Case Study Research. London: Sage publications.

\section{AUTHOR'S BIOGRAPHY}

Luciana Marques Vieira received a PhD in Agricultural and Food Economics from the University of Reading, United Kingdom. She is a senior lecturer of International Business in the Management Postgraduate Program (PPG) at Universidade do Vale do Rio dos Sinos (Unisinos) and a researcher at CNPq (Brazilian Ministry of Science and Technology). Her specific areas of interest and research include internationalization strategies, global chain management and international operations strategy.

Luís Kluwe Aguiar is a graduate from the Federal University of Rio Grande do Sul in Brazil. Has studied for his MSc in Agricultural Economics at the University of London-Wye College and is PhD candidate from the University of Bath. Presently, has a Senior Lecturer post at the Royal Agricultural College, in England, lecturing on marketing and international business. Since 2008 has acted as Link Tutor for Foundation Degree in Business Management and Course Manager for MBA in the Agriculture and Food Industries. Luís is also an Associate Lecturer at the Open University Business School. Main research interests focus on marketing and consumer studies especially relating to ethnic and ethical consumerism. Prior to becoming an academic, Luís worked for many years in the agribusiness sector in Brazil.

Marcia Dutra de Barcellos is a Researcher and Associate Professor at the Post Graduate Programme in Business School of the Federal University of Rio Grande do Sul (PPGA/UFRGS), Brazil. In 2008 she worked as a Post-Doctoral Researcher at the University of Aarhus, MAPP - Centre for Research on Customer Relations in the Food Sector in Aarhus, Denmark. She collaborates in international projects financed by the European Union and other international bodies (DEFRA, Enterprise Ireland, others). Marcia also coordinates research projects in food marketing, financed by the Brazilian Ministry of Science and Technology $(\mathrm{CNPq})$ and by the Foundation for the Support of Research in the State of Rio Grande do Sul (FAPERGS). Marcia has a Master's and a PhD Degree in Agribusiness from the Federal University of Rio Grande do Sul (CEPAN/UFRGS), Brazil. She was a guest PhD student at the Marketing and Consumer Behaviour Group from Wageningen University in The Netherlands and at the Meat Science Group from the University of New England, in Armidale, Australia. She has published in high-impact peer reviewed journals such as Appetite, Meat Science, BMC Public Heath, Livestock Science, Innovative Food Science and Emerging Technologies, Food Control, Brazilian Administration Review, Agroanalysis, Nutrición Hospitalaria, amongst others. 